\title{
SURVEY AND POPULATION DENSITY OF IMPORTANT INSECTS INFESTING CICHORIUM INTYBUS L. PLANTS DURING TWO SUCCESSIVE SEASONS AT QALUBIA GOVERNORATE , EGYPT
}

\author{
BADRAN, B.A. ${ }^{2}$, S. A. EL- DESSOUKI ${ }^{1}$, A.S.EL-KHOULY ${ }^{1}$ and M.F.A. HEGAB ${ }^{2}$ \\ 1- $\quad$ Faculty of Agric., Al- Azhar Univ. Cairo \\ 2- $\quad$ Plant Protection Research Institute, ARC, Dokki, Giza
}

(Manuscript received 12 May 2014)

\begin{abstract}
Survey of dominant insects occurred on Cichorium intybus , Asteraceae and their abundance were carried out throughout two successive seasons 2009/2010 and 2010/2011 at Qalubia governorate. The results showed that there are twelve insect species belonging to four orders and nine families were dominant on Chicory plant they were: Order : Diptera \{ Family Agromyzidae (Liriomyza trifolii (Burg), and Family Anthomyidae (Pegomia mixta (Witt.), Order: Hemiptera \{Family Aleyrodidae Bemisia tabaci (Genn), Family Aphididae (Aphis craccivora (Koch) , Aphis gossypii (Glover), and Myzus persicae (sulzer) , Family Cicadellidae (Empoasca spp.), Family Pentatomidae (Nezara viridula) and Family pseudococcidae (Planococcus sacchara (Cockerell), Order Lepidoptera \{ Family Noctuidae (Agrotis ipsilon (H.) and Spodoptera littoralis (Boisd.) and Order Thysanoptera \{ Family Thripidae (Thrips tabaci (lind) Population density of five insects infesting Chicory plants C. intybus $L$. was estimated during 2009 /2010 in the first season and the second season $2010 / 2011$, the study was insects studied were : L.trifolii ., B. tabaci ., A. gossypii, Empoasca spp., Th. tabaci . The obtained results showed that the white fly B.tabaci recorded the highest number (278.5 and 405.9 individuals / 5 leaves) followed by A. gossypii (2001and 238.7 individuals/5 leaves), Thrips tabaci (117.5 and 165.1 individuals /5 leaves), Empoasca spp (83.7 and 114.6 individuals / 5 leaves) and Liriomyza trifolii (74.8 and 107.6 individuals $\mid 5$ leaves) during first and second season, respectively.
\end{abstract}

\section{INTRODUCTION}

Chicory (Chicorium intybus L.), a perennial herb of the Asteraceae family, with blue, lavender flowers, also known as a blue sailors, endive, succory and coffeeweed, (New Medical College of Jiangsu, India, 1977) is native to the Mediterranean region, mid Asia and northern Africa. Historically, Chicory was grown by the ancient Egyptian as a medicinal plant, coffee substitute, vegetable crop and for animal forage (Plumier 1972 and Munoz, 2004). Today, it is cultivated in Europe and North America with many commercial uses e.g. salads, vegetable dishes, forage , boiled and eaten, dried and roasted and used as a coffee substitute and additive, 
important source of inulin (Herck and Bnert, 1999) and for ethanol production by direct fermentation kyazzeet et.al., 2008.

Many conducted researches reveal that the tumors inhibition of chicory root extracts against Ehelich ascites carcinoma were tested in mice and significant results were reported for doses obtained between $300-700 \mathrm{mg} / \mathrm{kg}$ (Hazara et.al. 2002) . That plant was introduced newly in Egypt and it is worth to notefy that no areas were cultivated commercially in Egypt except small areas for agricultural experiments, while ten countries around the world cultivate 23058 Hectares yielded 90224 ton rots with $397292 \mathrm{~kg} . / \mathrm{H}$. during 2012 . Entomological studies on Cichorium plants revealed that many insect attacking the plant such as Frankliniella occidentalis, Agriotes spp.,Deroreras reticulatum., Tipula spp., Blaniulus gyttulatus, Th. tabaci, Clivina fossor, Nasonovia ribis nigri, Autographa gamma, Apodemus sylvaticus, Mcrotus arvensis, L. trifolii , B.tabaci, A. gossypii and Empoasca spp.( Proft, 2000, Cosmi,et al 2003, Domenico et al, 2008, Benigni, 2011, Smith et al, 2011, Rodriguez et al 2012). So, these study aim to throw light on the insects infesting the Chicory plant and their population density during two successive season 2009 /2010 and 2010 /2011at Qalubia Governorate .

\section{MATERIALS AND METHODS}

The present studies were conducted during the period from the 1st of Oct. 2009 to the end of May 2011. 200 Square meters of agricultural land were chosen at Qaha res., station - Qalubia Governorate. In mid September, Chicory seeds were sown in rows of $50 \mathrm{~cm}$ Width with $20-25 \mathrm{~cm}$ between planting .Plants received the usual agricultural practices and chemical control was entirely avoided, the above mentioned area was divided to 3 equal replicates. This study was conducted by weekly inspections from the last week of Oct. 2009 to 15/5/2010 and from 30/10/2010 to $21 / 5 / 2011$ through the two experimental years 2009/2010 and 2010/2011respectivly. Two survey methods were applied during the present study. The first was direct counting technique for mature and immature stages of insects harboring the plants, while the second one was by picking 5 / leaves randomly as replicate. Plant samples were put in paper bags and transferred to laboratory for identified and counting them with help by using stereomicroscope .The species by specialists from Classification department of plant protection Research institute, Dokki, Giza. The surveyed insects were recorded. The population density for the most important insect pest was recorded species (from the three replicates). The means calculated form 5 leaves, also 
the insect samples started from 24/10/2009 to $15 / 5 / 2010$ during the first experimental season and from 30/10/2010 to $21 / 5 / 2011$ in the second exp. Season.

\section{RESULTS AND DISSCUSION}

I-Survey of dominant insects occurred on Cichorium intybus and their abundance were carried out throughout two successive seasons from Oct..2009 to May., 2011 at Qalubia governorate. The obtained results in Table (1) showed that there are twelve insect species belonging to four orders and nine families were dominant on Chicory plant they were:

1.Order : Diptera :1.1 Family Agromyzidae (Liriomyza trifolii (Burg), and 1.2Family Anthomyidae (Pegomia mixta (Witt.), 2.Order: Hemiptera 2.1 Family Aleyrodidae2.1.1 Bemisia tabaci ( Genn) ,2.2 Family Aphididae2.2.1 (Aphis craccivora (Koch) ,2.2.2 Aphis gossypii (Glover), and2.2.3 Myzus persicae (sulzer) ,2.3 Family Cicadellidae (Empoasca spp.) , 2.4Family Pentatomidae (Nezara viridula) (Westw) and 2.5Family pseudococcidae (Planococcus sacchara (Cockerell), 3.Order Lepidoptera 3.1 Family Noctuidae 3.1.1Agrotis ipsilon (H.) and 3.1.2Spodoptera littoralis (Boisd.) and 4.Order Thysanoptera 4.1 Family Thripidae 4.1.1(Thrips tabaci (lind).

\section{II- Population density of five insects infested Cichorium intybus during two successive seasons 2009/2010 and 2010/2011 in Qalubia Governorate :}

\section{Bemisia tabaci ( Genn):}

Results in Tables (2 and 3 ) and Fig. (1) reveal that the white fly infestation was higher in second tested season than the first one recording 13.53 nymphs/ 5 leaves and 9.3 nymphs / 5 leaves, respectively. The infestation started with 15.3 nymphs/5leaves in 24/10/2009 of the first tested season and increased gradually lasting to its highest mean 49.3 nymphs / 5 leaves in 14/11/2009, then decreased gradually lasting to its lower mean number 0.6 nymphs / 5 leaves, and then disappeared for seven weeks from 23 Jan. to 6 Mar. 2010. The insects appeared again during Mar. 2010 recording low numbers 2.3 at 13/3/2010 with light increas to the end of the growing season of Chicory plants recording 7.3 nymphs / 5 leaves at $15 / 5 / 2010$. The same trend of population fluctuation was observed during the second tested season $2010 / 2011$. The white fly $B$. tabaci was recorded a total numbers of 278.5 nymphs during the first examined season comparing with 405.9 nymphs during the second season 2010/2011.The same results were obtained by

Zanic, et al (2001) the presence of B. tabaci was also confirmed in gardens and private plots from July to October. This paper provides a detailed description of the 
morphology, biological and ecological characteristics, distribution and damage caused by B. tabaci.

\section{Empoasca spp}

The leaf hopper Empoasca spp was infestation higer in the second tested season (114.6 insects/5 leaves ) thanin the first season (83.7 insecta/5leaves) . In the first season 2009/2010 the leaf hopers infested the plants at the first sampling with (7.3 insects/5leaves) in 24/10/2009 then the population fluctuated high and low till $26 / 12 / 2009$. The Empoasca spp insects disappeared three weeks from $2 / 1 / 2010$, to $16 / 1 / 2010$,then appeared again by (30/1/2010 till 6/3/2010 except 1.3 insects recorded in the two samples of $8 / 2$ and $13 / 2 / 2010$. The insects of leaf hopper appear again from $20 / 3 / 2010$ by (1.6 insects / 5 leaves) and increased gradually lasting to its high infestation at the end of the chicory plants growing season recording (9.3 insects/5leaves).

Population density of the leaf hopper insects infesting chicory plants during the two tested seasons was relatively similar and had the same trend with ageneral mean of infestation ( 2.92 and 3.82 insects $/ 5$ leaves ) for the first and the second tested seasons, respectively.

\section{Thrips tabaci (lind)}

The optioned results recorded in Tables (2 and 3 ) and illustrated in Fig.(3) during the two tested seasons (2009/20/10 and 2010/2011),results indicating that the infestation with thrips insects firstly appeared with (2.6 insects / 10 leaves) at the first sample 24/10/2009.then increased and decreased during the following 7 weeks lasting to (2.6 insects /sampl).Thrips insects disappeared during the next 6weeks and again infested plants at the end of Jan. 2010 by 1.3 thris /sample. The infestation increased gradually during the period of the warm weather lasting to its high level 15.3 and 12.6 thrips /sample at $6 / 3$ and $13 / 3 / 2010$, respectively. During the remain period of the growing season 9week later the infestation was inhigh numbers recoding 8.6 insects /10leaves of chicory plants, the above mentioned finding were observed during the second tested season 2010/20011, while the general mean number was5.5 thrips/sample in the second tested season compared with lower mean 3.9 during the first season.The obtained results are in agree with those obtained by Smith et al (2011) and Rodriguez et al (2012)

\section{Aphis gossypit(Glover):}

The cotton aphid was the most damaging insect pest infesting chicory plants with high numbers during the two tested seasons. Results in Tables (2 and 3) and illustrated in Fig. (4) revealed, that the aphid infestation was higher in the second tested season (7.95 insects /sample)than in the first season (6.67/insectsper sample), 
stared with 4.3/sample at 24/10/2009 lasting to 1.6 aphids /sample at 26/12/2009, then the aphids disappeared for about one month and appeared again with (1.0 insect/sample) at 30/1/2010. The infestation increased gradually from 1.6 insects to its high level 19.3 insects /sample at 10/4/2010 lasting 11.3 insects at 15/5/2010 at the end of the growing season. The same trend of infestation was observed during the second tested season. The same result were obtained by Benigni, (2011) and Sanvicente et al (2011)

\section{Liriomyza trifolii (Burg)}

The results in Table 2 and Fig. 5 showed that the population density of L. trifolii recorded few number during the first weeks where it beginning 5.3 individuals 15 leaves on 24 Oct. then gradually decreased until disappeared during the period from 28Nov. 2009 to 13 Feb. 2010 in the first season, while Table 3 showed that the population started with few number ( 6.6 individuals | 5 leaves ) on 30 Oct. 2010 then gradually decreased until 4 Dec. where it record (1.3 individuals | 5 leaves ) and disappeared during the period from $11 \mathrm{Dec}$. to $5 \mathrm{Feb}$. In general, the population recovered again on $20 \mathrm{Feb}$. ( 2.6 individuals | 5 leaves ) and fluctuated in number to reached the highest number in the latest week of first season ( 11.3 individuals $\mid 5$ leaves ). The population started on $12 \mathrm{Feb}$. (1.3 individuals $\mid 5$ leaves ) and fluctuated to reached the peak in the latest week of the second season ( 13.6 individuals $\mid 5$ leaves. The mean total was 74.8 and 107.6 individuals' $\mid 5$ leaves in the first and second seasons, respectively.).

The chicory has been imported to Egypt by the researcher Dr Ahmad Atiah (2010) in Sugar crops Research inctitute, A gricultural Research of center to carry the studies that lead to increase the awareness on the importance of chicory it attacked by many pests namely, Bemisia tabaci (Genn),Aphis gossypii (Giover), Empoasca spp, Thrips tabaci (Lend.) and Liriomyza trifolili (Burg) which causimg heavy injuries to leaves and roots resulting reduced of production in quality and quantilty while some of them transmits virus deseases especially tomato spotted wilt virus (TSWV) transmitted by thrips species franlimiella occidentalis and Thrips tabaci (Cosmi et.al. 2003) 
1258 SURVEY AND POPULATION DENSITY OF IMPORTANT INSECTS INFESTING CICHORIUM INTYBUS L. PLANTS DURING TWO SUCCESSIVE SEASONS AT QALUBIA GOVERNORATE , EGYPT

Table 1. survey of insect pests infesting Cichorium intybus at Qalubia Governorate during 2009/2010 and 2010/2011 seasons.

\begin{tabular}{|c|c|c|c|c|c|}
\hline Order & Family & Investigated insects & $\begin{array}{c}\text { Abundance } \\
\text { degree }\end{array}$ & Stage & $\begin{array}{c}\text { Period } \\
\text { of } \\
\text { occurrence }\end{array}$ \\
\hline \multirow[t]{2}{*}{ Diptera } & Agromyzidae & $\begin{array}{l}\text { Liriomyza trifolii } \\
\text { (Burg) }\end{array}$ & +++ & Larvae & $\begin{array}{c}\text { October- November } \\
\text { February - June }\end{array}$ \\
\hline & Anthomyidae & $\begin{array}{c}\text { Pegomia mixta } \\
\text { (Witt.) }\end{array}$ & + & Larvae & April \\
\hline \multirow[t]{7}{*}{ Hemiptera } & Aleyrodidae & $\begin{array}{c}\text { Bemisia tabaci } \\
\text { (Genn.) }\end{array}$ & +++ & $\begin{array}{c}\text { Immature\& } \\
\text { Adult }\end{array}$ & $\begin{array}{c}\text { October-January } \\
\text { March - June }\end{array}$ \\
\hline & Aphididae & $\begin{array}{c}\text { Aphis craccivora } \\
\text { (Koch) }\end{array}$ & + & $\begin{array}{l}\text { Adult \& } \\
\text { Nymph }\end{array}$ & $\begin{array}{c}\text { October-December } \\
\text { April - May }\end{array}$ \\
\hline & Aphididae & $\begin{array}{c}\text { Aphis gossypii } \\
\text { (Glover) }\end{array}$ & +++ & $\begin{array}{l}\text { Adult \& } \\
\text { Nymph }\end{array}$ & $\begin{array}{c}\text { October- December } \\
\text { February - June }\end{array}$ \\
\hline & Aphididae & $\begin{array}{c}\text { Myzus persicae } \\
\text { (sulzer) }\end{array}$ & + & $\begin{array}{l}\text { Adult \& } \\
\text { Nymph }\end{array}$ & October-November \\
\hline & Cicadellidae & Empoasca spp & +++ & $\begin{array}{l}\text { Adult \& } \\
\text { Nymph }\end{array}$ & October- May \\
\hline & Pentatomidae & Nezara viridula & + & Adult & January, April \\
\hline & pseudococcidae & $\begin{array}{c}\text { Planococcus } \\
\text { sacchara (Cockerell) }\end{array}$ & + & Nymph & January \\
\hline \multirow[t]{2}{*}{ Lepidoptera } & Noctuidae & Agrotis ipsilon (H.) & + & Larvae & October-November \\
\hline & Noctuidae & $\begin{array}{c}\text { Spodoptera } \\
\text { littoralis (Boisd.) }\end{array}$ & + & Larvae & November \\
\hline Thysanoptera & Thripidae & $\begin{array}{c}\text { Thrips tabaci } \\
\text { (lind) }\end{array}$ & +++ & $\begin{array}{l}\text { Adult \& } \\
\text { Nymph }\end{array}$ & October- May \\
\hline
\end{tabular}


Table 2. Weekly mean numbers of insect pests per 5 plant leaves of Cichorium intybus at Qalubia governorate during 2009 / 2010 season.

\begin{tabular}{|c|c|c|c|c|c|}
\hline Date & Bemisia tabaci & Empoasca spp, & $\begin{array}{l}\text { Thrips } \\
\text { tabaci }\end{array}$ & $\begin{array}{r}\text { Aphis } \\
\text { gossypii }\end{array}$ & Liriomyza trifolii \\
\hline $24 / 10 / 2009$ & 15.3 & 7.3 & 2.6 & 4.3 & 5.3 \\
\hline $31 / 10 / 2009$ & 24.9 & 8.3 & 1.6 & 8.3 & 3.3 \\
\hline 07/11/2009 & 32.9 & 2.6 & 4.3 & 5.6 & 2.3 \\
\hline $14 / 11 / 2009$ & 49.3 & 1.3 & 3.3 & 12.3 & 2.6 \\
\hline $21 / 11 / 2009$ & 35.6 & 2.3 & 2.3 & 5.6 & 1.6 \\
\hline $28 / 11 / 2009$ & 22.6 & 3.3 & 1.6 & 4.3 & 0 \\
\hline 05/12/2009 & 13.3 & 3.6 & 1.3 & 3.6 & 0 \\
\hline $12 / 12 / 2009$ & 12.9 & 4.6 & 2.6 & 2.6 & 0 \\
\hline $19 / 12 / 2009$ & 11.6 & 3.3 & 0 & 1.6 & 0 \\
\hline $26 / 12 / 2009$ & 3.9 & 2.3 & 0 & 1.6 & 0 \\
\hline 02/01/2010 & 5.6 & 0 & 0 & 0 & 0 \\
\hline 09/01/2010 & 3.9 & 0 & 0 & 0 & 0 \\
\hline $16 / 01 / 2010$ & 0.6 & 0 & 0 & 0 & 0 \\
\hline $23 / 01 / 2010$ & 0 & 2.6 & 0 & 0 & 0 \\
\hline $30 / 01 / 2010$ & 0 & 0 & 1.3 & 1 & 0 \\
\hline 06/02/2010 & 0 & 1.3 & 2.3 & 1.6 & 0 \\
\hline $13 / 02 / 2010$ & 0 & 1.3 & 1.3 & 2.6 & 0 \\
\hline 20/02/2010 & 0 & 0 & 2.6 & 4.3 & 2.6 \\
\hline $27 / 02 / 2010$ & 0 & 0 & 3.3 & 4.3 & 1.6 \\
\hline 06/03/2010 & 0 & 0 & 15.3 & 3.6 & 2.3 \\
\hline $13 / 03 / 2010$ & 2.3 & 0 & 12.6 & 5.6 & 4.3 \\
\hline $20 / 03 / 2010$ & 1.9 & 1.6 & 7.3 & 7.6 & 2.3 \\
\hline $27 / 03 / 2010$ & 4.9 & 2.6 & 8.3 & 12.3 & 3.6 \\
\hline 03/04/2010 & 2.6 & 3.6 & 9.6 & 13.3 & 4.3 \\
\hline $10 / 04 / 2010$ & 5.3 & 4.3 & 5.6 & 19.3 & 5.6 \\
\hline $170 / 4 / 2010$ & 3.3 & 5.6 & 3.3 & 12.6 & 3.3 \\
\hline 24/04/2010 & 6.3 & 6.7 & 3.6 & 17.3 & 4.6 \\
\hline 01/05/2010 & 4.6 & 3.3 & 7.3 & 18.3 & 5.3 \\
\hline 08/05/2010 & 7.6 & 2.6 & 5.6 & 15.3 & 8.6 \\
\hline $15 / 05 / 2010$ & 7.3 & 9.3 & 8.6 & 11.3 & 11.3 \\
\hline Total & 278.5 & 83.7 & 117.5 & 200.1 & 74.8 \\
\hline Mean & 9.3 & 2.790 & 3.917 & 6.670 & 2.493 \\
\hline
\end{tabular}


1260 SURVEY AND POPULATION DENSITY OF IMPORTANT INSECTS INFESTING CICHORIUM INTYBUS L. PLANTS DURING TWO SUCCESSIVE SEASONS AT QALUBIA GOVERNORATE , EGYPT

Table 3. Weekly mean numbers of insect pests per 5 plant leaves of Cichorium intybus at Qalubia governorate during 2010 /2011 season.

\begin{tabular}{|l|c|c|c|c|c|}
\hline Date & $\begin{array}{c}\text { Bemisia } \\
\text { tabaci }\end{array}$ & $\begin{array}{c}\text { Empoasca } \\
\text { Spp. }\end{array}$ & $\begin{array}{c}\text { Thrips } \\
\text { tabaci }\end{array}$ & $\begin{array}{c}\text { Aphis } \\
\text { gossypii }\end{array}$ & Liriomyza trifolii \\
\hline $30 / 10 / 2010$ & 20.3 & 10.3 & 5.3 & 7.3 & 6.6 \\
\hline $06 / 11 / 2010$ & 24.9 & 10.3 & 4.3 & 9.6 & 4.3 \\
\hline $13 / 11 / 2010$ & 34.6 & 4.6 & 5.6 & 7.6 & 3.6 \\
\hline $20 / 11 / 2010$ & 53.3 & 3.3 & 7.3 & 10.3 & 3.6 \\
\hline $27 / 11 / 2010$ & 39.9 & 4.6 & 2.3 & 10.6 & 2.3 \\
\hline $04 / 12 / 2010$ & 28.9 & 3.6 & 3.3 & 4.6 & 1.3 \\
\hline $11 / 12 / 2010$ & 18.9 & 5.3 & 4.3 & 7.6 & 0 \\
\hline $18 / 12 / 2010$ & 17.3 & 7.3 & 3.6 & 3.3 & 0 \\
\hline $25 / 12 / 2010$ & 13.6 & 4.6 & 0 & 3.6 & 1.3 \\
\hline $01 / 01 / 2011$ & 7.6 & 4.3 & 0 & 1.6 & 0 \\
\hline $08 / 01 / 2011$ & 8.9 & 0 & 2.3 & 1.3 & 0 \\
\hline $15 / 01 / 2011$ & 8.3 & 1.3 & 0 & 0 & 0 \\
\hline $22 / 01 / 2011$ & 1.3 & 0 & 1.3 & 0 & 0 \\
\hline $29 / 01 / 2011$ & 0 & 0 & 0 & 1.3 & 0 \\
\hline $05 / 02 / 2011$ & 0 & 0 & 1.6 & 0 & 0 \\
\hline $12 / 02 / 2011$ & 0 & 0 & 3.6 & 0 & 1.3 \\
\hline $19 / 02 / 2011$ & 0 & 0 & 3.3 & 2.3 & 3.3 \\
\hline $26 / 02 / 2011$ & 0 & 0 & 7.3 & 5.6 & 1.6 \\
\hline $05 / 03 / 2011$ & 2.6 & 0 & 17.6 & 5.3 & 3.3 \\
\hline $12 / 03 / 2011$ & 8.3 & 2.3 & 14.6 & 4.6 & 5.3 \\
\hline $19 / 03 / 2011$ & 7.9 & 1.6 & 10.6 & 8.6 & 4.6 \\
\hline $26 / 03 / 2011$ & 10.9 & 3.6 & 10.6 & 9.3 & 4.3 \\
\hline $02 / 04 / 2011$ & 11.9 & 3.3 & 9.3 & 14.3 & 2.6 \\
\hline $09 / 04 / 2011$ & 13.3 & 4.3 & 8.6 & 17.3 & 7.3 \\
\hline $16 / 04 / 2011$ & 14.6 & 5.6 & 3.3 & 21.6 & 5.6 \\
\hline $23 / 04 / 2011$ & 11.6 & 4.6 & 5.3 & 14.3 & 5.3 \\
\hline $30 / 04 / 2011$ & 9.6 & 9.3 & 4.6 & 18.6 & 7.6 \\
\hline $07 / 05 / 2011$ & 12.9 & 5.6 & 8.3 & 20.3 & 7.3 \\
\hline $14 / 05 / 2011$ & 10.6 & 4.3 & 7.6 & 14.6 & 11.6 \\
\hline $21 / 05 / 2011$ & 13.9 & 10.6 & 9.3 & 13.3 & 13.6 \\
\hline Total & 405,9 & 114,6 & 165,1 & 238,7 & 107,6 \\
\hline Mean & 13,53 & 3,82 & 5,503 & 7,957 & 3,587 \\
\hline
\end{tabular}


Bemisia tabaci

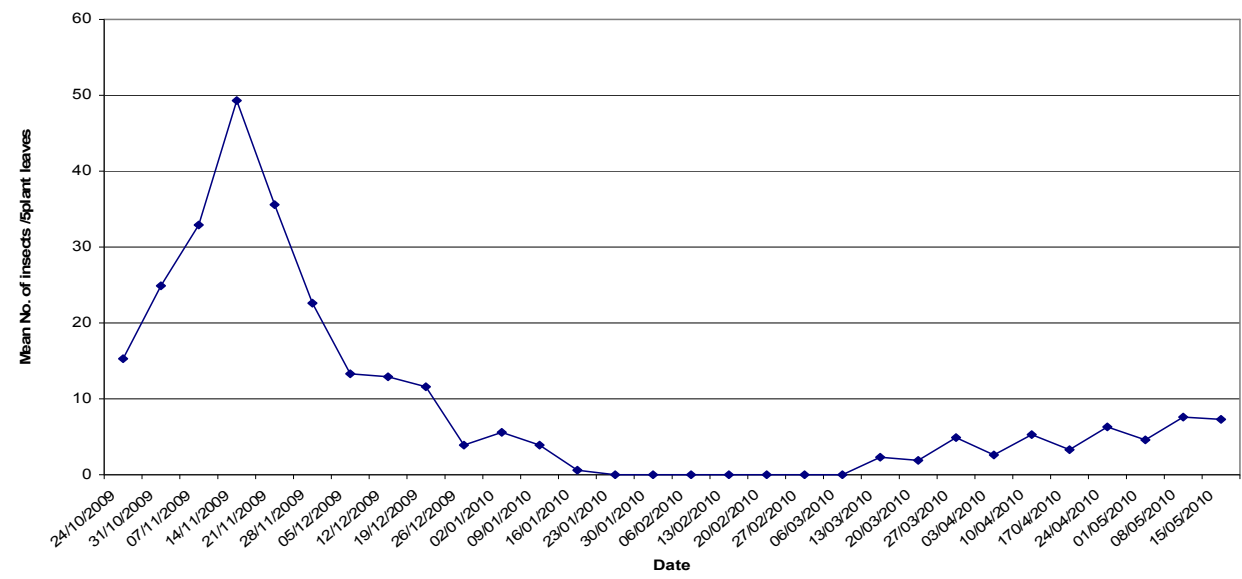

$2009 / 2010$

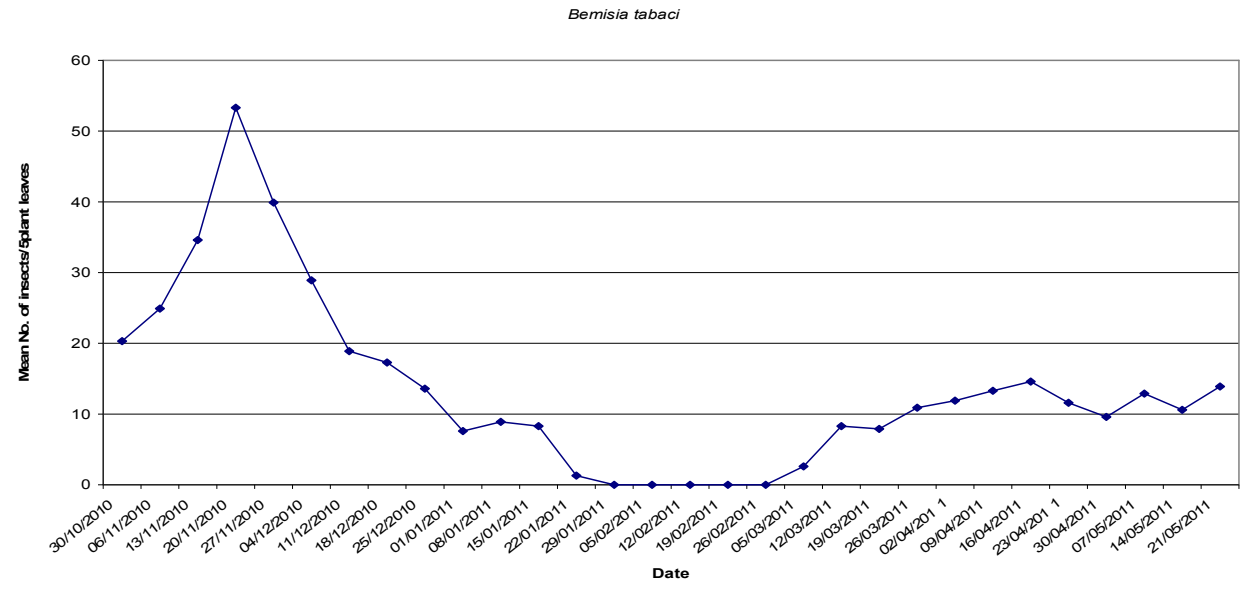

$2010 / 2011$

Fig 1. Weekly mean numbers of Bemisia tabaci per 5 plant leaves infesting Cichorum intybus plants at AL-Qalubia governorate, during the two seasons investigated. 
Empoasca spp

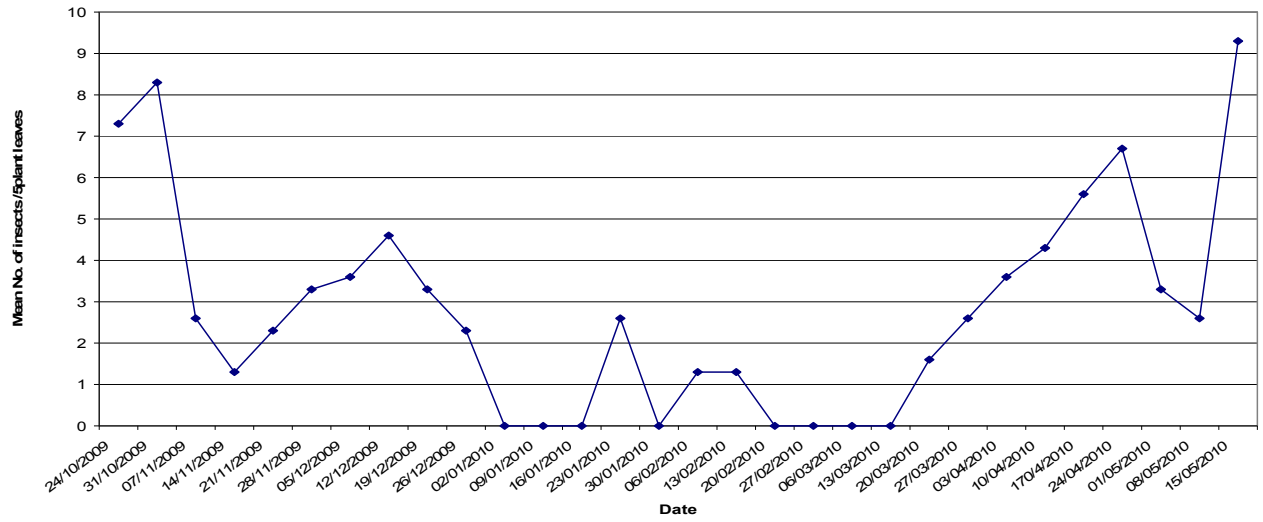

$2009 / 2010$

Empoasca Spp.

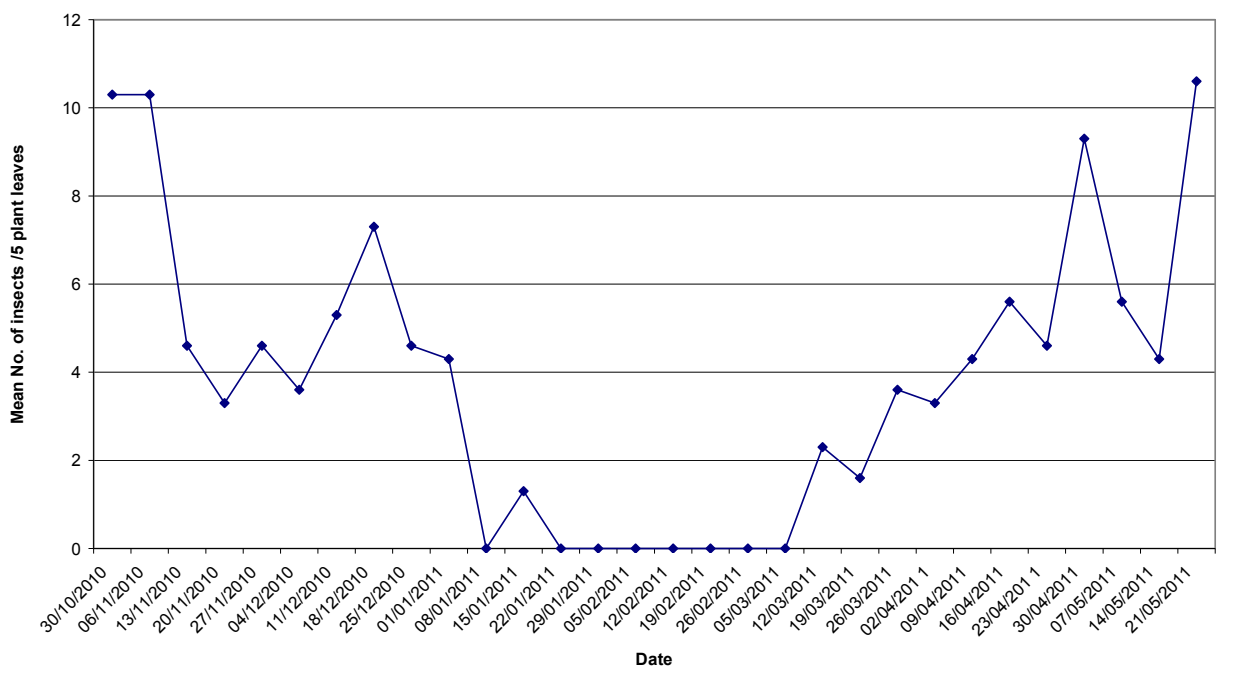

$2010 / 2011$

Fig 2. Weekly mean numbers of Empoascal spp. per 5 plant leaves infesting Cichorum intybus plants at AL-Qalubia governorate during the two seasons investigated. 
Thrips tabaci

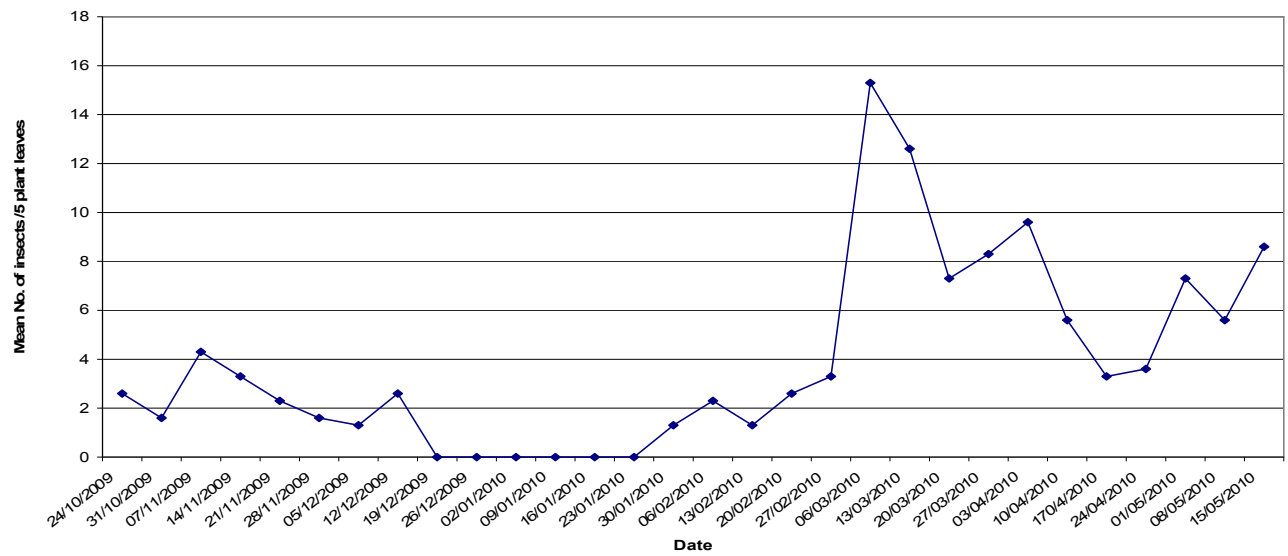

$2009 / 2010$

Thrips tabaci

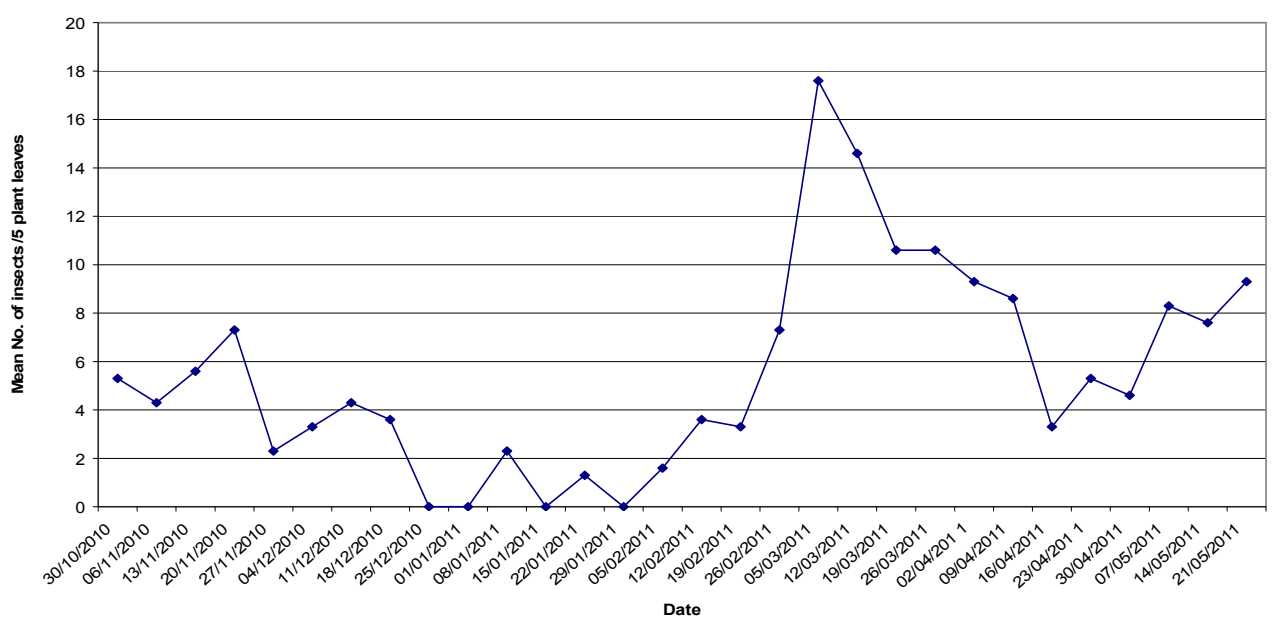

Fig 3. Weekly mean numbers of Thrips tabaci per 5 plant leaves infesting Cichorum intybus plants at AL-Qalubia governorate during the two seasons investigated 
1264 SURVEY AND POPULATION DENSITY OF IMPORTANT INSECTS INFESTING CICHORIUM INTYBUS L. PLANTS DURING TWO SUCCESSIVE SEASONS AT QALUBIA GOVERNORATE , EGYPT

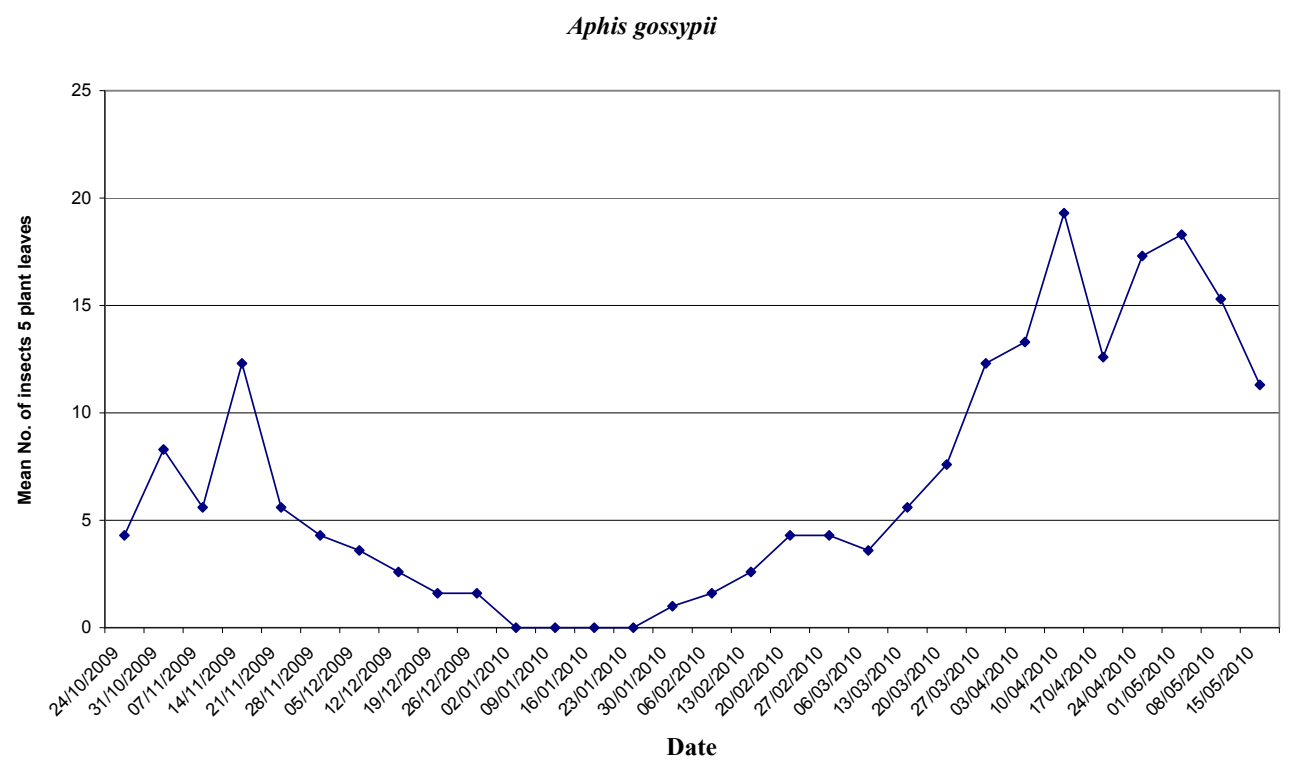

$2009 / 2010$

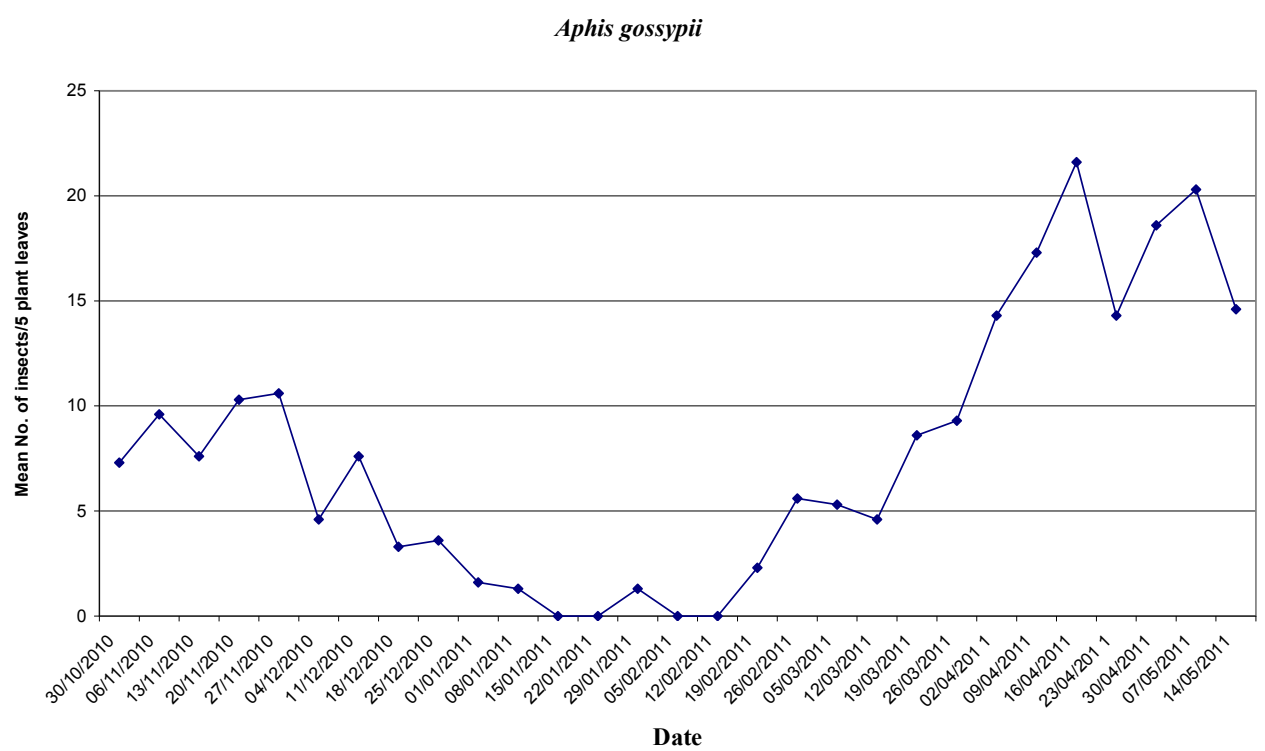

Fig 4. Weekly mean numbers of Aphis gossypii per 5 plant leaves infesting Cichorum intybus plants at AL-Qalubia governorate during the two seasons investigated. 


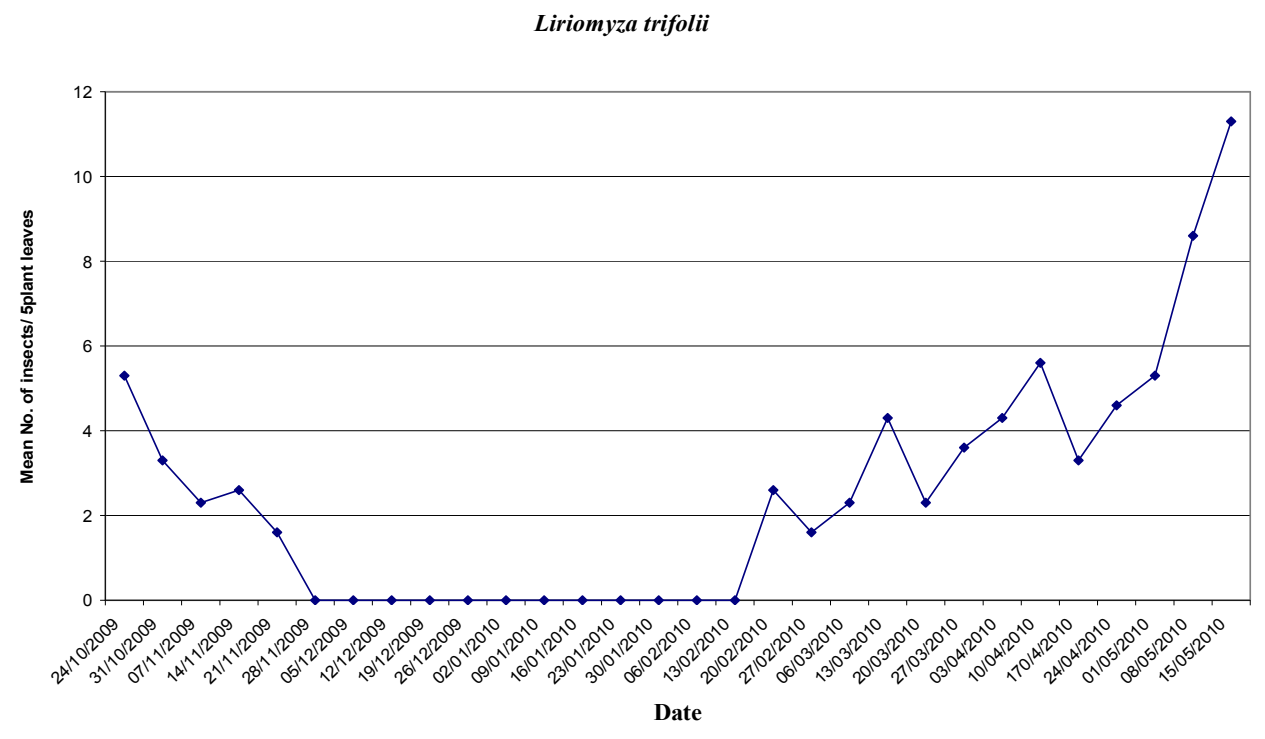

$2009 / 2010$

Liriomyza trifolii

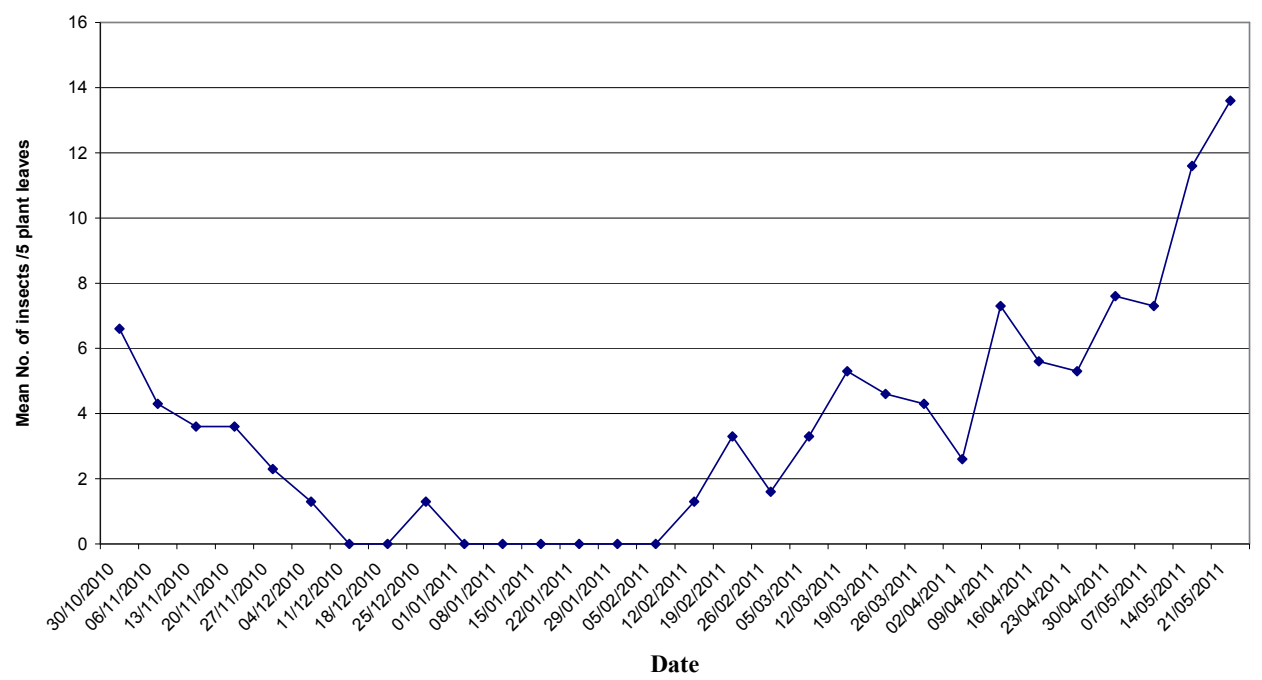

Fig 5. Weekly mean numbers of Liriomyza trifolii per 5 plant leaves infesting Cichorum intybus plants at AL-Qalubia governorate during the two seasons investigated.

\section{REFERENCES}

1. Benigni, M. 2011. Possibilities of integrated control of main pests and diseases of witloof chicory culture. [French] 4eme Conference Internationale sur les Methodes Alternatives en Protection des Cultures. Evolution des cadres reglementaires europeen et francais. Nouveaux moyens et strategies Innovantes, Nouveau Siecle, Lille, France, 842-850.

2. Cosmi, T., Marchesini, E. and Martini,G. 2003. Presence nd spread of Tospovirus and thrip vectors in Veneto. [Italian] Informatore Agrario,. 59: 20, 69-72. 
3. Delamey, john H. 1915. Dept. of Efficiency and Economy Annual Report .Albany New York, , p.673.

4. Domenico D'Ascenzo, D.and Di Silvestro, D. 2008. Protecting lettuce,endive, chicory and radicchi [against diseases and pests]. [Italian] Informatore Agrario,. 64: 18, 27-30, 33-35.

5. Hazara B., Sarkar R., Bhattacharyya S. and Roya P. 2002. Tumour inhibitory activity of chicory root extract against Ehrlich ascites carcinoma in mice. Fitoterapia, 73: 730-733 .

6. Herck JCV and Baert J. 1999. The selection of chicory in full development. Betteravier (Bruxelles). 33: 17-18.

7. Kyazze,G., Dinsdale , R., Haukes , F.R., Guwry , A.jy . premier , G.C. and Donnison , I., s. 2008. Direct fermentation of fodder maize, chicory fructans and perennial ryegrass. To hydrogen using mixed microflora Bioresour Technol., 99(18) : 8833-8839 .

8. Munoz C.L.M. 2004. Spanish medicinal plants: Cichorium intybus L. Boletin de laReal Socieded Espanola de Hisoria Natural, 99: 44-47.

9. Nakhmetov, FG. Golubev AD,Orkina NL,Maykhina ES, Kulyasova Nv. and Lashevich LP.19991. Manvfacture of soluble chicory with milk .USSR palant 16.3429.

10. Ramamoorthy, K., Vantitha,C. and Sivasubramaniam,K. 2006. Herbal hydration dehydration with hicory leaf extract for vigour and vibility in sunflower (helianthus annuus L.). Res., on Crop, 7(3):881-884.

11. Rodriguez, J., Neira, P. and Carrizo, P. 2012. Seasonal variation of Thripidae in cherry orchards and vegetation associated with culture in the Lower Valley Chubut River, Argentina. [Spanish] RIA, Revista de Investigaciones Agropecuarias,. 38: 1, 46-54.

12. Proft, M. de 2000. Pest of chicory. [French]. Betteravier (Bruxelles),. 35: 363369.

13. Plumuier, W . 1972. Chicory improvement. Revuede l'Agric, 4: 567-585.

14. Sharma, A.D., Sandeep, K. and Gill, P.K. 2006. Inulinase production using garlic (Allium sativum) powder as a potential substrate in Streptomyces Streptomyces sp.Journal-of-Food- Engineering. 77(3) : 486-491.

15. Sanvicente, P., Benigni, M., Cassan, L. 2011. Lettuce root aphid (Pemphigus bursarius) on Witloof chicor Y: status and outlook. [French]Infos- Ctifl,. 277, 5661.

16. Smith, E. A., Ditommaso, A., Fuchs, M., Shelton, A. M.and Nault, B. A. 2011. Weed hosts onion thrips (Thysanoptera: Thripidae) and their potential role in the epidemiology of Iris yellow spot virus in an onion ecosystem. Environ. Entomol.,. 40: 2, 194-203.

17. Snepp,S,S. and Kravchenko A. 2009. Rotational and cover determinants of soil structural stability and carbon data Br J. NUTR.93 513-590. 


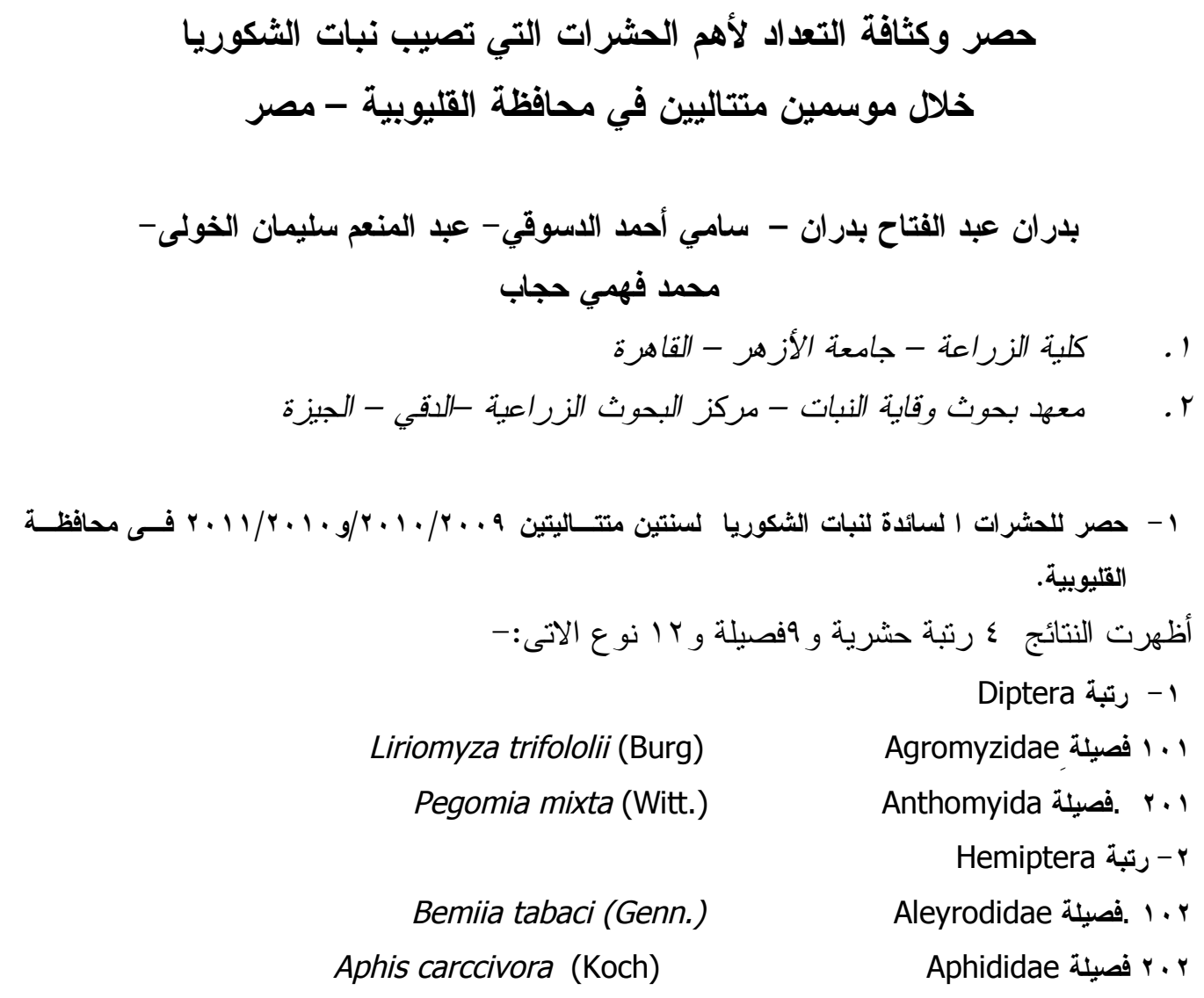

Aphis gossypii (Glover)

Myzus persicae (Sulzer)

Empoasca spp.

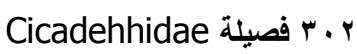

Nezara viridula

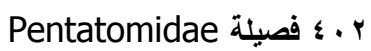

Planococcus sacchara (Cockerell) (Cockerell)

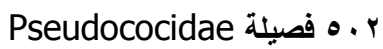

Lepidoptera r- برتبة

Agrotis ipsilon $(\mathrm{H})$

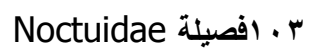

Spodoptera littoralis (Boisd)

Thrips tabaci(Lind)

ك كرتبةa

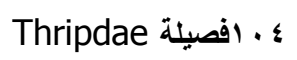

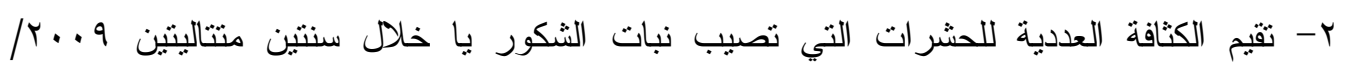

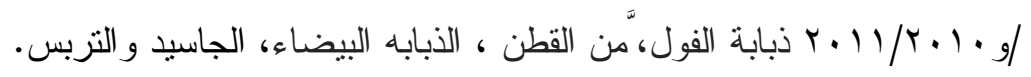

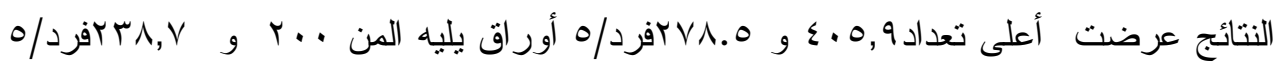

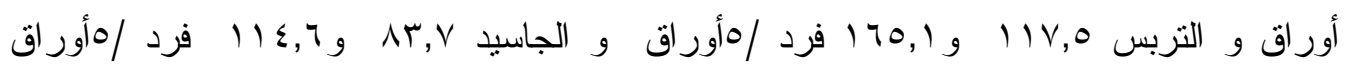

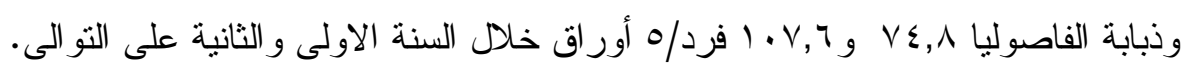

